\title{
Science, Tradition and Scholarship: Restoring Trust to Higher Learning in Iceland
}

\section{Thorolfur Thorlindsson ${ }^{1}$}

\begin{abstract}
In this paper I argue that the academic culture, politics and the organization of the University of Iceland has been characterized by three cultures that I label as the literary, the civic, and the Humboldtian traditions. These traditions have mixed with new ideologies and social movements, vast social and economic changes, and specific historical events in shaping the University. I speculate about the role of the '68 movement, as a critical element in this complex development as well as the efforts of Rector Gudmundur K. Magnusson to restore credibility and trust in the University of Iceland during the 1980s. I acknowledge that this is a first report on an ongoing project. The views presented in this paper should therefore be considered as tentative and hypothetical.
\end{abstract}

JEL: H83, I21, I23, L32, Z19.

Key concepts: Science, tradition, relativism, university management.

1 Thorolfur Thorlindsson is a Professor at the Faculty of Social Sciences, University of Iceland. The Paper was presented at the symposium in honour of Professor Gudmundur Magnusson, University of Iceland, Reykjavik, November 2007. 


\section{Introduction}

Borne out of the ideologies of democracy, national independence and historical pride, the University of Iceland brought new professionalism to higher learning, government and public administration in Iceland. The University of Iceland provided scholarship and education in the Icelandic language, history, culture and literature as well as the Latin and Greek classics to help the Icelanders to theorize about their identity and their place in the world. The University of Iceland also trained civil servants and professionals for a society heading towards independence. These elements combined to form a scholarly civic and literary tradition that was nested in nationalistic ideas.

The University of Iceland also fostered from the beginning hopes of becoming an institution that combined science, scholarship and learning in the quest for knowledge. Inspired by the Humboldtian notion of the research university, this quest was seen as a key mission of the new university by its first rector, Bjorn M. Olsen. This scientific tradition was in many ways different from both the civic and the literary traditions. It emphasized academic freedom, the scientific community of peers and scientific achievement in an international context.

The three traditions, the literary, the civic, and the Humboldtian, have influenced the development and the internal politics of the University of Iceland from the day it was founded up to the present. Over the years these traditions have mixed with new ideologies and social movements. Thus ideas have come from business, politics, theories of management and political ideologies. Often these ideologies were intertwined with the vast social and economic changes and specific historical events that brought new challenges for higher education.

One historical event that played a role in this complex development was the student movement of the '68-generation. It undermined traditional authority that was crucial for the power structure at the time, opened up several avenues for new developments. At the same time it reduced the credibility of the University in the eyes of public officials and politicians and made them question unconditional financial support for the University. The break with tradition may have paved the way for the Humboldtian type research university in the sense that it undermined the norms pertaining to the power and status of higher civil servants. The ideology of the "68-student movement may also have hindered the development of science at the University of Iceland. Its emphasis on epistemic relativism and anti-scientific attitude, especially in the social sciences and the humanities, undermined the respect and importance of science. The '68-student movement also questioned the objective nature of science, its neutrality and its "cold and calculating" approach to human affairs. The decline of traditional authority and the anti-scientific rhetoric that dominated the public discussion in higher education discredited the main sources for legitimating public financial support for the University. In this paper I speculate about the role of the ' 68 movement as one element in the complex mixture of traditions and ideologies that have shaped the development of the University of Iceland. I also discuss the efforts of Rector Gudmundur K. Magnusson to restore the credibility and trust in the University of Iceland during the 1980s in the aftermath of 
the student revolt. This is a first report on an ongoing project that is still taking shape. Empirical material is still being collected. The views presented in this paper should therefore be considered as tentative and hypothetical.

\section{The Three Founding Cultures of the University of Iceland}

The University of Iceland included from its conception ideas from three different traditions that influenced its education, scholarship and organization. These ideas formed a tradition that focused on educating civil servants for the emerging independent society, preserving and expanding the Icelandic cultural heritage, training scientists and promoting science. This scholarly tradition had strong nationalistic elements that provided a major justification for the establishment of the University and shaped its organization and its educational policy in the first decades. The three professional schools, theology, medicine and law, which were the forerunners of the university, were established to secure higher civil servants to meet the need of Icelandic society and culture. A need, that higher education in Denmark could not meet. It is, in fact, clear from the discussion preceding the establishment of the University of Iceland that the priority was to establish a school to educate priests and ministers, medical doctors and lawyers, not a university that focused on science and academic research (see e.g. Jónsson, 1961, pp. 11-20). Teaching science was to come later. However, combining the three professional schools together to form a new institution, the University of Iceland, drew attention to the German idea of the research university. The disciplines of theology, medicine, and law that were to fulfil a practical need for priests, lawyers and medical doctors, also brought a spirit of academic scholarship and a belief in science that was celebrated in the opening ceremony on June 17th, 1911, when the University of Iceland was formally established. Thus, the mission of the University of Iceland, from day one, also included ideas from the international community of science, emphasizing collegial type of government, academic freedom and the spirit of scientific inquiry.

\subsection{Educating Civil Servants}

The perceived need to provide professional services in the areas of law, medicine and religion, which are vital for defining and maintaining a full-fledged modern society, provided a major incentive to establish the University of Iceland. The training of Icelandic lawyers to develop and interpret the law, run the courts and the legal establishment was a central task for the establishment of the emerging new republic. Educating lawyers abroad in Denmark did not satisfy the spirit of independence that characterized the times. Icelandic students complained constantly that Danish law schools did not take notice of Icelandic law (Snævarr, 1961; Jónsson, 1961, pp. 12 -20). Also, it seems highly plausible that Danish law did not satisfy the professional ambition of a profession that listed Grágás among its accomplishments. Furthermore, the Icelandic connection is, of course, crucial for public administration and institution building in the development of full-fledged and independent national state. In order to cover all these areas it was necessary to establish a law school in Iceland which was accomplished in 1908. 
It was also important to provide the critical religious service to the nation that was more than $90 \%$ protestant. The religious institutions were important to both the social and cultural organization of the Icelanders as well as the public system of government. The priests performed all the basic ceremonies that were so crucial to the functioning of an independent society with an independent culture. Baptizing the newborns, confirmation ceremonies, weddings and funerals were core functions of the social system that needed to be performed in the proper way by the proper authorities. Religion was also central to the classical tradition that had considerable influence on scholarship and education in Iceland at the beginning of the twentieth century. The classics had considerable influence on higher education and characterized the secondary school curriculum. Religion also played an important role in establishing both the humanistic and the social science tradition within the University of Iceland. It provided a scholarly connection with the classical tradition of higher learning.

Medicine provided the third foundation for the civil tradition. A medical school was founded in Iceland in 1876. The medical profession was in the beginning strongly connected to the top level of civil servants including the Surgeon General (landlæknir) at the top. Also, it became an important bridge towards the natural sciences. Furthermore, the faculty of medicine played a key role in taking up issues related to scientific research. Thus the medical faculty were instrumental in pushing for funds for research, emphasizing academic freedom and the importance of science within the University of Iceland (Davíðsson, 1961).

The legal, religious, and medical studies formed the foundations of the new civil tradition of higher education in Iceland. At the same time the faculties involved kept alive the vision of a full-fledged university with a strong research agenda.

\subsection{The Literary Tradition}

Icelanders developed a unique literary tradition that dates back to the middle Ages. Writers and poets have been writing about the history and the culture of Iceland since the twelfth century. The Sagas, along with other medieval literature, reveal the social context and the cultural patterns, values, and norms that define key social institutions and guide behaviours. This literature of medieval Iceland was central to the Icelanders' creating and recreating themselves. It provided the social and cultural base for a new nation to build on. It has helped to preserve the Icelandic language, create national consciousness and strengthened social and cultural continuity. The Icelandic Sagas have been a constant source of national sentiments that have taken on various forms over the centuries. They were highlighted by the Romantic Movement in the nineteenth century where they provided a great inspiration for the independence movement. These sources about medieval society have provided an abundance of material that provides exciting challenges for researchers. At the same time, they encouraged a unique scholarly and literary tradition that has influenced higher learning in Iceland and played a key role in shaping the University of Iceland up to this day. 


\subsection{The Scientific Tradition}

The modern research university is just one of many types of institutions of higher learning in the plethora of colleges and universities that flourish in the modern world. While research and scholarship had been a part of universities for centuries the modern research university really gained momentum after World War II. The expansion of higher education in the 20th century was, in part, driven by the belief that science and knowledge played an important role in societal progress and human welfare. Research became an even more salient part of higher education, especially in Europe and the U.S., leading to the development of the successful research university. Two ideas were particularly influential in creating the research university. The first idea, most often attributed to Von Humboldt, emphasizes that research and teaching should be integrated to form a unique institution where these two scholarly activities are seen as mutually supportive elements of the academic process (Bertilsson, 1992; Thorlindsson, 1994), characterizing both the role of the academic faculty and the mission of the university. To be an academic, one has to be committed to transmitting and producing knowledge. The symbiotic relationship between research and teaching became a cornerstone of the modern research university. It furthers the view that research and teaching should be grounded in the academic disciplines, the rules of scientific inquiry, and the communities of scholars that work within any given field of science.

An important idea in the development of the research university was the acceptance of the linear model of innovation. The model holds that science that pursues knowledge for its own sake is the foundation from which practical, industrial and technological innovations come. Basic scientific knowledge is applied to solve practical problems and produce new technologies. This linear model has now been rejected for a more accurate one that emphasizes a complex interaction between the academic and the practical aspects of the innovative process. It, however, provided a strong utilitarian justification for funding university research without much demand for immediate concrete practical results. It was simply held that the best way to strengthen technical and industrial innovation was to provide a generous support to basic research. Furthermore, it was held that the best way to locate basic research was within the universities.

Incorporating science into the university in a systematic way brought ideas and standards that influenced it in a fundamental way. Scientific work is constrained by strict codes of standards and procedures regarding all aspects of research. These codes have a strong technological base that details the planning of research; collecting; analyzing; interpreting and publishing findings (Merton, 1973; Ziman, 1994). But they also involve a pattern of behaviour, beliefs and principles that define the membership in the community of scientific experts committed to guide the truth as it stands at any time. Scientists are members of a social community that obliges them to cite, acknowledge, evaluate, criticize and endorse the work of their colleagues. Furthermore, the system of science also brought an organization that emphasized collegial government, academic freedom, academic entrepreneurship and curiosity driven research (Thorlindsson, 2005; Ziman, 1994). Finally, more and more of the university budget came directly and indirectly from research. This 
meant that good researchers became increasingly important to the university. Indeed, researchers who brought in money directly through research grants, and indirectly by increasing the prestige of the university, would automatically be more independent and could back up their claims for freedom financially. Thus the flow of research money into the university strengthened academic freedom and the independence of the faculty.

\section{The Scholarly Traditions and the Organization of the University of Iceland}

There are many ways to organize and to govern the modern university. Its organization and power structure are shaped by many traditions that have mixed together over the years. The financial, social and political environment in which the university operates, also shape its organization. Finally, the development of science itself is constantly offering new opportunities and proposing new challenges. The University of Iceland is certainly no exception. Its organization and style of governance is a mixture of traditions that have evolved over time in response to new developments and outside demands. It involves elements of academic culture, emphasizing independence and political freedom. Tenured faculty has had considerable freedom to teach and pursue academic topics of interest. The formal structure within the University of Iceland has also been characterized by collegial approach to power and authority. The faculty (and later also students) elects rectors and departmental chairs as well as many major committees. The University Council, which is the highest functioning body within the University of Iceland, has been composed of faculty and students during most of the history of the University.

At the same time, the faculty were government employees who were expected to behave as "civilized public servants" that adhered, in part, to the same code as the higher level civil servants and diplomats (Thorlindsson, 2006).

Regarding the development of the University of Iceland up into the late 80s Thórir Kr. Thórðarson (1986) argued that it changed from a school focusing on the education civil servants to a full-fledged research university. While this development is now becoming increasingly clearer, it is also becoming more evident that this is not a consistent linear development. There seem to have been critical phases in this development revolving around critical issues and challenges.

These issues may often involve various combinations of internal conflicts, framed by the different traditions within the university, changing business climate and downsizing of public expenditures. Sometimes they involve historical events that shake the foundations of the university. One such event was the '68 student revolution. It questioned the basic foundation of the university, its power base and the nature of scientific inquiry.

\section{The University of Iceland in the Age of Radical Relativism}

Good management of public institutions is a major source of trust and credibility. Well-managed and responsible institutions are arguably worth the funds that they receive, while poorly managed institutions are a waste of public money. One 
important criterion is that the system of government should be both transparent and in line with the latest management theories. Usually the governing style of university is neither. Convincing politicians and public officials that universities are well run is, however, not an easy task. In most cases this difficult task becomes the responsibility of the rector of the university.

The rector of the University of Iceland has always had a good opportunity to tackle the issues involved in building trust and reputation. As the liaison between the University and the Ministry of Education, the rector decides, in many cases, what important issues should be given priority. The rector also mediates and interprets the formal messages that go back and forth between the Ministry and the University. Placed in an ambiguous situation, representing the scholarly culture of peers on one hand and the Ministry of Education on the other, offers the rector a range of choices to do his or her work. Some rectors may place themselves closer to the collegial model of governance while others may see themselves more as civil servants, almost as an extension of the Ministry of Education. Some may take up a flexible position moving back and forth, mediating and negotiating between different groups and traditions (Thorlindsson, 2006).

Professor Ármann Snævarr, who was the rector of the University of Iceland for nine years during the 60s, tried to pick up the pace and push the University of Iceland towards becoming a research university. He wanted to place more emphasis on the natural and social sciences (Personal Communication). So did the current Minister of Education at that time, Gylfi Th. Gíslason. Together these two leaders succeeded in setting the course of the University of Iceland towards a full-fledged modern research university. This plan was halted by an unforeseen development: the student revolt of the ' 68 generation.

After Ármann Snævarr left the rector's office in 1969, Magnús Már Lárusson took office for a relatively short period. But it was Guðlaugur Thorvaldsson who received the difficult task of keeping the University of Iceland together and steering it through the troubled waters of the 70s. That he did with great skill. He managed to keep the peace and avoid major disturbances. He supported the increased role of students in boards and committees. Much of the rector's work during that period was directed at internal politics and maintaining the university function from day to day. At the same time there was increased distrust and scepticism towards the University on the part of government officials. They felt that the student revolt was undermining the proper education and training at the University.

The 1968 student revolt and its aftermath had significant influence on the development of the University of Iceland. The movement brought radical scepticism and strong disregard for authority, tradition and any conventional status hierarchy. Thus it questioned the traditional authority and the status hierarchy of the civil University. In the long run this development probably paved the way for other types of organization, including the collegial approach to university organization that characterized the scientific community. The student movement also emphasized freedom and individual rights that harmonized well with collegiality and academic freedom. More importantly, the student movement explicitly aligned forces with 
those who wanted to strengthen the role of the sciences in the curriculum (Sigfúsdóttir, 1997). This is especially the case for the social sciences where the contribution of the students proved to be decisive (Sigfúsdóttir, 1997).

The student movement also brought strong anti-scientific sentiments that portrayed science as conservative, cold and calculated and even anti-humanistic. Furthermore, the student movement of 1968 was characterized by a heavy dose of relativism that was to have great influence, especially in the humanities and the social sciences. While it is true that the '68-movement focused in the beginning on cultural or moral relativism it carried quickly over into the academia focusing on the epistemological base of science. Science as an institution was also a tempting target in the sense that it was often linked to power and wealth that were part of status quo.

The rejection of the "positivistic" views of science and the anti-scientific sentiments promoted by the student movement undermined reputation and trust, two key sources of success for universities. These two vital characteristics for universities derive, in part, from the fact that universities are institutions of science. Science produces reliable knowledge. It searches for the truth in a systematic way.

Universities thrive on trust and reputation. This is certainly the case for a university like the University of Iceland that builds its financial existence on public money that comes directly out of the government budget. While it stands to reason that universities that provide good solid education and produce quality research are worthy of generous financial support, the measures of quality are neither clear nor transparent.

Restoring trust to the University of Iceland was the challenging task faced by Professor Gudmundur K. Magnusson who was elected rector in 1979. His victory was in many ways surprising. Trained as an economist, Professor Gudmundur K. Magnusson was well known as a spokesman for the free market, deregulation and economic competition. He was considered to be on the right wing of the political spectrum. For him to win the election for rector of the University of Iceland at a time when left wing politics dominated the scene was a considerable achievement.

Rector Gudmundur K. Magnusson was from the beginning faced with the problem of restoring credibility to the University, increasing public support and securing public funds. Rector Magnusson's effort to restore credibility and increase public trust in the University of Iceland revolved around three issues. First, he wanted to demonstrate that the University of Iceland was an institution of science rather than an institution with a political agenda. He wanted to redraw the boundaries between science and politics. Distinguishing science from non-science or pseudoscience is at the heart of University organization. Universities reject some topics on the grounds that they are unscientific and accept others as part of their scientific curriculum. Thus in everyday practice science is constantly being redefined. Within the institution of science, scientist themselves are constantly differentiating between science and nonscience, good science and bad science. Focusing on the scientific method and the notion of objectivity Gudmundur made an effort in a classical Weberian style (Weber, 1949) to draw these lines. 
It is, however, not always possible to codify the scientific method in absolute terms. Science attempts to work with ideas and assess evidence, step by step, according to explicit guidelines. Thus, in science one must set up experiments according to some rules, using control groups, double blind experiments and statistical tests to evaluate outcomes. Also, scientific inquiry should be carried out in an open context where every aspect of the process should be carefully spelled out for others to check and verify. Although it is not always possible to draw a clear line between science and pseudo-science, it seems evident that institutions that are organized around these basic principles of science bring reliability and a sense of objectivity that is a primary source of trust and reputation for any university. The strong stand taken by the rector on issues regarding science was widely supported by faculty. It played an important role in restoring trust in the University of Iceland as an institution of science. Also, it supported the elements within the University that wanted to move towards a research university.

One important effort by Rector Gudmundur K. Magnusson to strengthen science was to establish a science fund at the University of Iceland. The fund supported research on the basis of the quality of applications that were reviewed by peers. The establishment of the University Science Fund increased financial support for research, and drew attention to the quality of research and the system of peer review. The discussion and the increased awareness of the importance of the peer review system sharpened the focus on quality of research and drew attention to what passes for good, bad, and pseudo-science. Running the Science Funds also draw attention to issues such as what projects should be supported and who should be rejected, what studies were good enough science to be published in scientific journals and who should be hired and who should be fired from scientific institutions.

The second aspect of Rector Magnusson's effort to restore trust in the University was to adopt better financial management practices. He made a great effort to increase transparency of the decision-making regarding the budget and allocation of money within the University. He worked closely with both government officials and politicians to reach this goal. He improved the management of University funds. And he set up and activated committees that included people from the University and the ministries that discussed the issues regarding the University budget and exchanged information about important financial and political matters.

The third part of the rector's strategy was to prove that the University could make hard and responsible decisions on its own. One goal of the '68 movement was to abolish formal authority and hierarchical power structures. Students, faculty and staff should have equal say in all maters regarding the University. Rector Magnusson opposed this and made a strong effort to restore proper authority to the governing bodies of the University in accordance to its formal system of governance. He also wanted to demonstrate that there was no need for outside interference to secure order and good educational policy. Thus rector Magnusson made sure that all the difficult decisions about university matters were taken within the University

The Rector's effort to restore trust in the University as a well managed institution where objective research of high standard was being conducted was successful. It led 
to a three year contract between the Icelandic government and the University that was much more generous than the previous contracts that were operated on yearly basis. In fact, it turned out to be one of the most generous agreements in the history of the University.

\section{Conclusion}

I have suggested above that the University of Iceland has, from the beginning, been characterized by three traditions that have mixed together over the years to form a full-fledged research university of international standing. At the same time, the University of Iceland has served the Icelandic society well, providing it with civil servants, ministers, lawyers, physicians and teachers at all levels. The University of Iceland has also played a central role in preserving and expanding the Icelandic language, literature and history. Finally, the University of Iceland plays a key role in producing expertise for the modern Icelandic knowledge society. In short, the University of Iceland is becoming more and more important for all areas of Icelandic society. One reason for this is that science plays an increasingly bigger role in the economy. Another reason is that the scope of science is expanding in the democratic process where policy makers, politicians and the media are searching for a scientific base on which to make political decisions or to support regulatory policy.

At the same time, the social context of the University of Iceland is becoming more and more complex and both the social organization and the practice of teaching and research are becoming more diverse. This process has lead to increasing problems of demarcation of science. It has also made the social organization of science more complex where boundaries are being drawn and redrawn not only between science and pseudo-science but also within the ever-expanding institution of science.

The future success of the University of Iceland will depend on how well it meets the new challenges of the day. But it will just as well depend on preserving what makes the University of Iceland a special institution. Knowing what to throw away and knowing what to keep thus holds the key to a successful future of a university that has to compete in the global community of scientific institutions and preserve the national cultural heritage of a small nation at the same time. If this challenging task can be accomplished with an academic organization that does not loose sight of substantive aims as well as high intellectual standards of scholarship, it will in due course bring prosperity and progress.

\section{References}

Bertilson, M. (1992). From University to Comprehensive Higher Education: on the Widening Gap between 'Lehre und Leben'. Higher Education, 24, 333-349.

Davíðsson, D. (1961). Læknavísindi á Íslandi. In Eldjárn, K., Bjarnason, Ó. \& Pórarinsson, S. (Eds.), Vísindin efla alla dáð: afmæliskveðja til Háskóla Íslands 1961 (pp. 193-201). Reykjavik: Bandalag Háskólamanna. 
Gieryn, T. F. (1983). Boundary-Work and the Demarcation of Science from NonScience: Strains and Interests in professional Ideologies of Scientists. American Sociological Review, 48, 781-795.

Jónsson, G. (1961). Saga Háskóla Íslands: Yfirlit yfir hálfrar aldar starf. Reykjavík: Háskóli islands.

Merton, R. (Ed.) (1973). The Sociology of Science: Theoretical and Empirical Investigation. Chicago: Chicago University Press.

Sigfúsdóttir, I. D. (1997). Námsbraut í almennum pjóðfélagsfræðum: áfangi að stofnun nýrrar deildar. Íslensk félagsrit, 7.-9. árg., 1995-1997, 7-40.

Snævarr, Á. (1961). Hugleiðingar um lögfræðikennslu og lögfræðinám. In Eldjárn, K., Bjarnason, Ó., \& Pórarinsson, S. (Eds.), Vísindin efla alla dád: afmæliskveðja til Háskóla Íslands 1961 (pp. 135-149). Reykjavík: Bandalag Háskólamanna.

Thórðarson, T. K. (1986). Frá embættismannaskóla til vísindaseturs. Tímarit Háskóla Íslands 1986, 1 (1), 11-14.

Thorlindsson, T. (2006). Embætti rektors í stjórnartíð Sigmundar Guðbjarnasonar. In Guðmundur G. Haraldsson (Ed.) Vísindin heilla - Afmælisrit til heiðurs Sigmundi Guðbjarnasyni 75 ára (pp. 401-422). Reykjavík: Háskólaútgáfan.

Thorlindsson, T. (2005). Organizing the Research University in the Knowledge Society: The Importance of Academic Science. In Ö. D. Jonsson \& E. H. Huijbens (Eds.) Technology in Society in Technology (pp. 131-172). Reykjavik: The University of Iceland Press.

Weber, M. (1949). The Methodology of the Social Sciences. Three essays edited and translated by Shils, E. A., \& Finch H. A. New York: The Free Press.

Ziman, J. (1994). Prometheus Bound: Science in a Dynamic Steady State. Cambridge: Cambridge University Press. 
